This is an electronic reprint of the original article. This reprint may differ from the original in pagination and typographic detail.

\author{
Author(s): Hankala, Mari; Kankaanranta, Marja; Kepler-Uotinen, Kaili; Rousi, Rebekah; Mehtälä, \\ Saana
}

Title: $\quad$ Towards a scenario of virtual mental health environments for school-aged children

Year: $\quad 2017$

Version:

Please cite the original version:

Hankala, M., Kankaanranta, M., Kepler-Uotinen, K., Rousi, R., \& Mehtälä, S. (2017). Towards a scenario of virtual mental health environments for school-aged children. In Academic MindTrek'17 : Proceedings of the 21st International Academic MindTrek Conference (pp. 239-242). Association for Computing Machinery (ACM).

https://doi.org/10.1145/3131085.3131100

All material supplied via JYX is protected by copyright and other intellectual property rights, and duplication or sale of all or part of any of the repository collections is not permitted, except that material may be duplicated by you for your research use or educational purposes in electronic or print form. You must obtain permission for any other use. Electronic or print copies may not be offered, whether for sale or otherwise to anyone who is not an authorised user. 


\section{Towards a scenario of virtual mental health environments for school-aged children}

\section{Poster}

\author{
M. Hankala \\ Department of Teacher Education \\ University of Jyväskylä \\ P.O. Box 35 \\ FI-40014 University of Jyväskylä \\ Finland \\ mari.hankala@jyu.fi
}

\author{
M. Kankaanranta \\ Faculty of Information Technology \& \\ Finnish Institute for \\ Educational Research \\ P.O. Box 35 \\ FI-40014 University of Jyväskylä \\ Finland \\ marja.kankaanranta@jyu.fi
}

\author{
K. Kepler-Uotinen \\ Department of Teacher Education \\ University of Jyväskylä \\ P.O. Box 35 \\ FI-40014 University of Jyväskylä \\ Finland \\ kaili.kepler-uotinen@jyu.fi
}

\author{
R. Rousi \\ Faculty of Information Technology \\ University of Jyväskylä \\ P.O. Box 35 \\ FI-40014 University of Jyväskylä \\ Finland \\ rebekah.rousi@jyu.fi
}

\author{
S. Mehtälä \\ Faculty of Information Technology \\ University of Jyväskylä \\ P.O. Box 35 \\ FI-40014 University of Jyväskylä \\ Finland \\ saana.s.s.mehtala@student.jyu.fi
}

\begin{abstract}
This study explores student teachers' future design scenarios focusing on promoting children's mental health literacy through virtual reality (VR) environments. VR use is on the verge of many breakthroughs in several areas of lived experience. One such area pertains to educational contexts. Student teachers were chosen as the subjects of this study due to the likelihood that they will be the primary users and disseminators of these emerging technologies in educational contexts. The students created five types of future scenarios that contained different environments and activity modes, including those that are still not yet feasible to realize with current technological capabilities. The aims students set for the VR worlds were closely in-line with the transversal competences defined in the Finnish curriculum framework. They also reflected many topics of mental health learning.
\end{abstract}

\section{CCS CONCEPTS}

- Applied computing $\rightarrow$ Education; Interactive learning environments - Human centered computing $\rightarrow$ Interaction paradigms; Virtual reality

\section{KEYWORDS}

Virtual reality (VR), mental health, student teacher, school-aged children, digital literacy, scenario

Permission to make digital or hard copies of part or all of this work for personal or classroom use is granted without fee provided that copies are not made or distributed for profit or commercial advantage and that copies bear this notice and the full citation on the first page. Copyrights for third-party components of this work must be honored. For all other uses, contact the Owner/Author.

\author{
AcademicMindtrek'17, September 20-21, 2017, Tampere, Finland \\ (C) 2017 Copyright is held by the owner/author(s). \\ ACM ISBN 978-1-4503-5426-4/17/09. \\ https://doi.org/10.1145/3131085.3131100
}

\section{INTRODUCTION}

The need for efficient and high quality digital programs for learning mental health literacy is accentuated in current school development initiatives and efforts in many countries. School communities are seen as instrumental components of the digital mental health literacy pursuit. In particular, schools are vehicles through which students are introduced to a range of alternative services and environments in the digital realm. For example, in Finland the new curriculum framework [1] has a strong emphasis on arranging schoolwork in such a way that supports both learning and wellbeing. Furthermore, it additionally focuses on so-called transversal competences, or 21 st century skills [2]. This entails that issues related to mental health should also be addressed throughout the curriculum.

The digital space opens up opportunities for people to seek information, interact, and take action in a manner through which they may maintain relative anonymity [3]. It enables the ability to distance oneself from familiar circles in order to engage in mental health issues. Moreover, it affords extra opportunities for gaining knowledge regarding the nature, characteristics and prominence of mental health related issues. 
Digitally based mental health solutions that are currently available include serious gaming for children, youth and adults [4] as well as online therapies, chats and motivational interviews [5]. Furthermore, rather than seeing cyberspace as detached from the physical world, it should be acknowledged that children and teenagers are spending increasing amounts of time in cyberspace. They are not only playing games, engaging in entertainment and learning, but also managing offline experiences such as friendships, meetings and events. In order to thrive in online and offline environments, children and teenagers need multiple digital literacies [6].

The aim of this poster is to explore future scenarios that were created by student teachers, regarding the design of virtual reality (VR) environments intended to promote mental health literacy. The reason for conducting the study with student teachers is due to the likelihood that they will be the primary users and disseminators of these emerging technologies in educational contexts. The study is a part of a multi-disciplinary consortium "Awareness, prevention and early intervention" (APEX) that focuses on digital mental health literacy and its promotion among children and young people, in their families, as well as social and school environments.

\section{Virtual reality (VR) in promoting mental health and digital mental health literacy}

It is predicted that VR will be an instrumental tool in healthcare in the near future, covering areas from surgery, surgical planning, training and rehabilitation [7] [8]. VR has also enabled the development of tailored mental health interventions which are high in fidelity, for the purposes of e.g., simulations, cognitive behavioral therapy and psychotherapy [9] [10]. Earlier studies have emphasized the potential of VR for assisting in the treatment of diverse phobias [11]. VR has additionally been utilised in the treatment of eating, self-esteem and self-image related disorders [12] [13]. Despite the fairly extensive research on the usage of VR in adults, there has not been much research targeting the effects of immersive technologies on children [14].

From the educational point of view, there have been some studies attempting to explore the learning and teaching potential of immersive environments. The potential of using augmented reality (AR) in teaching and especially in the context of elementary math education has been explored in cooperation with elementary school teachers and game designers teaching [15] and a game that leverages AR has been designed in the attempt to improve literacy skills in preschool-aged children [16]. In recent studies [15] [17], it has been shown that teachers often do not have a realistic understanding of the capabilities of AR technologies. They might overestimate the current capabilities of the technology, or present ideas that are not, in fact related to AR [15]. This highlights the need to improve teachers' knowledge of immersive technologies.

\section{METHOD AND DATA}

The study included two teacher education courses that were conducted during the spring term of 2017, at the Department of Teacher Education, University of Jyväskylä, as a part of a Master of Education degree program. Two student teacher groups (21 and 17 students) participated in a phenomena based course which combined Finnish language and literature with health education. The main phenomenon of the course was digital mental health literacy which was a logical theme for an interdisciplinary course of the two subjects. This poster focuses on part 3 of the course (see table 1).

Table 1: The structure of the Finnish language and literature and Health education combined course.

\begin{tabular}{|c|c|c|}
\hline $\begin{array}{l}\text { Course } \\
\text { structure }\end{array}$ & Related question & Related tasks \\
\hline $\begin{array}{l}\text { Part 1: } \\
\text { Theoretical } \\
\text { background }\end{array}$ & $\begin{array}{l}\text { How can we (as } \\
\text { future primary } \\
\text { school teachers) } \\
\text { promote pupils' } \\
\text { digital mental } \\
\text { health literacy? }\end{array}$ & $\begin{array}{l}\text { 1) Building knowledge of } \\
\text { digital literacy and digital } \\
\text { mental health literacy } \\
\text { based on literature } \\
\text { 2) Participating in group } \\
\text { discussions about literature }\end{array}$ \\
\hline $\begin{array}{l}\text { Part 2: } \\
\text { Practical } \\
\text { understanding }\end{array}$ & $\begin{array}{l}\text { How do I describe } \\
\text { my own digital } \\
\text { health literacy and } \\
\text { how can I support } \\
\text { pupils' literacy? }\end{array}$ & $\begin{array}{l}\text { 1) Evaluating and testing } \\
\text { own information retrieval } \\
\text { skills } \\
\text { 2) Creating criteria for } \\
\text { pupils to evaluate digital } \\
\text { mental health solutions } \\
\text { 3) Organising an evaluation } \\
\text { session with children }\end{array}$ \\
\hline $\begin{array}{l}\text { Part 3: } \\
\text { Future } \\
\text { scenarios }\end{array}$ & $\begin{array}{l}\text { How can virtual } \\
\text { reality } \\
\text { environments } \\
\text { support pupils' } \\
\text { mental health? }\end{array}$ & $\begin{array}{l}\text { 1) Personally trying on a } \\
\text { head-mounted display } \\
\text { (HMD) } \\
\text { 2) A group discussion } \\
\text { about virtual environment } \\
\text { planning } \\
\text { 3) Planning a virtual } \\
\text { environment targeted to } \\
\text { children or teenagers: VR } \\
\text { Scenario Stories }\end{array}$ \\
\hline
\end{tabular}

The data consists of 34 VR scenario stories written by student teachers. Most stories are one page in length, describing VR environments in which students envision how mental health literacy may be fostered. The stories were a part of the students' final reports where they reflected what they had learned during the course.

Stories were analyzed by conventional content analysis, where the coding categories were derived directly from the text data [18]. In our case, the stories were read by two researchers, categorized and classified firstly on the basis of their main themes. 


\section{RESULTS}

The results focus on describing students' scenario types and characteristics of the VR worlds. Although many students described more than one kind of VR scenario, the scenarios can be categorized into five main scenario types of virtual worlds. Table 2 presents these scenario types, aims and activities children would be able to do in the VR worlds in the order of frequency.

Table 2: Categories of the scenario types, included aims for mental health learning and activity affordances.

\begin{tabular}{|c|c|c|}
\hline $\begin{array}{l}\text { Scenario } \\
\text { type }\end{array}$ & Aim & Activity \\
\hline $\begin{array}{l}1 . \\
\text { Dreamland } \\
\text { worlds }\end{array}$ & $\begin{array}{l}\text { To make } \\
\text { children's } \\
\text { dreams visible } \\
\text { and strengthen } \\
\text { their mental } \\
\text { well-being } \\
\text { resources. }\end{array}$ & $\begin{array}{l}\text { For situations when children } \\
\text { want to relax or escape when } \\
\text { they feel very sad or } \\
\text { distressed. } \\
\text { Children can experience } \\
\text { positive and happy feelings, } \\
\text { feel dignified and important. }\end{array}$ \\
\hline $\begin{array}{l}\text { 2. My } \\
\text { worlds }\end{array}$ & $\begin{array}{l}\text { To learn about } \\
\text { feelings and } \\
\text { communication } \\
\text { skills in safe } \\
\text { conditions. }\end{array}$ & $\begin{array}{l}\text { To practice empathy and how } \\
\text { to be in a group. The } \\
\text { environments are e.g. cafés. }\end{array}$ \\
\hline $\begin{array}{l}\text { 3. Travel, } \\
\text { culture and } \\
\text { lifestyle } \\
\text { world }\end{array}$ & $\begin{array}{l}\text { To raise } \\
\text { cultural } \\
\text { knowledge, } \\
\text { language skills } \\
\text { and through } \\
\text { these self- } \\
\text { awareness. }\end{array}$ & $\begin{array}{l}\text { The possibility to travel in } \\
\text { different worlds and cultures } \\
\text { as well as in the home } \\
\text { country. } \\
\text { Travel in place or in time to } \\
\text { see, e.g., cities and go } \\
\text { sightseeing, and see nature } \\
\text { during different seasons. }\end{array}$ \\
\hline $\begin{array}{l}\text { 3. Win your } \\
\text { fears and/or } \\
\text { develop } \\
\text { your self- } \\
\text { knowledge } \\
\text { worlds }\end{array}$ & $\begin{array}{l}\text { To win } \\
\text { challenging } \\
\text { situations and } \\
\text { fears. }\end{array}$ & $\begin{array}{l}\text { Step by step programs where } \\
\text { children move from easy to } \\
\text { more difficult levels to face } \\
\text { their fears in safe conditions. } \\
\text { Tasks to promote their self- } \\
\text { esteem at every level. Worlds } \\
\text { are adapted to users' } \\
\text { individual needs. }\end{array}$ \\
\hline $\begin{array}{l}5 . \text { Healthy } \\
\text { worlds }\end{array}$ & $\begin{array}{l}\text { To raise } \\
\text { consciousness } \\
\text { about the } \\
\text { importance of } \\
\text { sleep and } \\
\text { physical } \\
\text { activities in } \\
\text { relation to } \\
\text { well-being. }\end{array}$ & $\begin{array}{l}\text { Ties, e.g., real world } \\
\text { information from a sleep } \\
\text { tracker to the VR world and } \\
\text { helps children understand the } \\
\text { meaning of good sleep. } \\
\text { Possibilities for example } \\
\text { trying various types of sport } \\
\text { to find out which one } \\
\text { interests them. }\end{array}$ \\
\hline
\end{tabular}

\section{Characteristics of the VR worlds}

The characteristics of the VR worlds can additionally be described through the operational logic of the worlds, i.e., in terms of the way the virtual worlds are designed to support the idea of the world and its affordances to serve user's needs. The analysis revealed the following overlapping categories: 1) SIMS like simulation worlds where children can choose elements and create their own environments, 2) guided, ready worlds where children obey instructions and solve problems, 3) playful game worlds, and 4) step by step worlds where children walk through a path comprising various stages.

\section{DISCUSSION}

The study was a tentative effort to explore possible VR scenarios for the promotion of children's mental health literacy. Currently, many virtual environments designed for mental health purposes focus on medical-related issues and mental disorders. Notably, earlier studies have indicated the positive effects of treating adults' mental health disorders in VR worlds. However, in the near future, VR use will experience many breakthroughs in various areas of people's daily lives, including educational contexts. Thus, in this study, we aimed at the comprehensive conceptualization of mental health issues that could be covered by the Finnish primary education curriculum. The results - the students VR scenarios - offered inspiring insights regarding the diverse affordances of future technologies (VR technologies) in enabling children to strengthen their capabilities in digital mental health literacy.

The student teachers created five kinds of future scenarios to support children's mental health. Students' imaginary worlds contained different environments and activity modes - even those that are currently not realizable with today's technologies. The aims students set for the VR worlds were closely in-line with the transversal competences defined in the Finnish curriculum framework. They also reflected many topics of mental health learning.

There is a need for more in-depth study to be undertaken regarding how we construe and understand the type of digital literacies needed in when venturing into the worlds of VR. The results of this scenario study indicated precisely this. According to the students' scenarios, there are clear similarities with many digital game genres [19], and VR worlds entail diverse types of literacies such as game literacy, procedural literacy and seemingly new forms of literacies that remain to be seen in the next phases of our studies on digital mental health literacy [20].

From the educational perspective, we will next invite children and young people with their teachers to evaluate student teachers' VR scenarios. We will also invite them to imagine their own scenarios. From the design perspective, we will determine design principles essential for the actual design of such mental health VR worlds. Future scenarios are needed to guide both the design of quality VR worlds as well as to develop teaching and learning practices for the versatile use of such VR worlds in diverse learning contexts - both at school and informal learning contexts. 


\section{REFERENCES}

[1] The Finnish National Board of Education (2016). National Core Curriculum for Basic Education 2014. (Publications 2016:5, Translation: Lingosoft Oy). Helsinki: Next Print Oy

[2] Ahonen, A. K., \& Kankaanranta, M. (2015). Introducing assessment tools for 21st century skills in Finland. In Assessment and Teaching of 21st Century Skills (pp. 213-225). Springer Netherlands.

[3] McKenna, K.Y., \& Bargh, J. A. (2000). Plan 9 from cyberspace: The implications of the Internet for personality and social psychology. Personality and social psychology review, 4(1), 57-75.

[4] Miller S.M. (2015). The Potential of Serious Games as Mental Health Treatment. University Honors Thesis. Paper 148. Portland: Portland State University.

[5] Dowling, M., \& Rickwood, D. (2013). Online counseling and therapy for mental health problems: A systematic review of individual synchronous interventions using chat. Journal of Technology in Human Services, 31(1), 1-21.

[6] Eshet, Y. (2012). Thinking in the Digital Era: A Revised Model for Digital Literacy. Issues in Informing Science and Information Technology, 9, 267-276.

[7] Adamovich, S. V., Fluet, G. G., Tunik, E., \& Merians, A. S. (2009). Sensorimotor training in virtual reality: a review. NeuroRehabilitation, 25(1), 29-44.

[8] McCloy, R., \& Stone, R. (2001). Virtual reality in surgery. BMJ: British Medical Journal, 323(7318), 912.

[9] Kim, G. J. (2005). A SWOT analysis of the field of virtual reality rehabilitation and therapy. Presence: Teleoperators and Virtual Environments, 14(2), 119-146.

[10] Riva, G. (2005). Virtual reality in psychotherapy: review. Cyberpsychology \& behavior, 8(3), 220-230.

[11] Gregg, L., \& Tarrier, N. (2007). Virtual reality in mental health. Social psychiatry and psychiatric epidemiology, 42(5), 343-354.

[12] Aymerich-Franch, L., Kizilcec, R. F., \& Bailenson, J. N. (2014). The relationship between virtual self similarity and social anxiety. Frontiers in human neuroscience, 8,944 .

[13] Keizer, A., van Elburg, A., Helms, R., \& Dijkerman, H. C. (2016). A Virtual Reality Full Body Illusion Improves Body Image Disturbance in Anorexia Nervosa. PloS one, 11(10), e0163921.

[14] Bailey, J. O. \& Bailenson, J. N. (2017) Considering virtual reality in children's lives, Journal of Children and Media, 11:1, 107-113.

[15] Radu, I., McCarthy, B., \& Kao, Y. (2016, March). Discovering educational augmented reality math applications by prototyping with elementary-school teachers. In Virtual Reality (VR), 2016 IEEE (pp. 271-272). IEEE.

[16] Bhadra, A., Brown, J., Ke, H., Liu, C., Shin, E. J., Wang, X., \& Kobsa, A. (2016, March). ABC3D-Using an augmented reality mobile game to enhance literacy in early childhood. In Pervasive Computing and Communication Workshops (PerCom Workshops), 2016 IEEE International Conference on (pp. 1-4). IEEE.

[17] Rousi, R. (2016). Using human-values as a guide for understanding worthy design directions in augmented reality. In Academic MindTrek'16 : Proceedings of the 20th International Academic MindTrek Conference (pp. 243-252). New York: Association for Computing Machinery (ACM).

[18] Hsieh, H. F., \& Shannon, S. E. (2005). Three approaches to qualitative content analysis. Qualitative health research, 15(9), 1277-1288.

[19] Elliott, L., Golub, A., Ream, G., \& Dunlap, E. (2012). Video game genre as a predictor of problem use. Cyberpsychology, Behavior, and Social Networking, 15(3), 155-161.

[20] Merchant, G. (2009). Literacy in virtual worlds. Journal of research in reading, 32(1), 38-56. 